\title{
Dietary level of maize oil affects growth and lipid composition of Walker 256 carcinosarcoma
}

\author{
BY J. MARK BLACK, ${ }^{1}$ MALDEN C. NESHEIM, ${ }^{2}$ AND JOHN E. KINSELLA ${ }^{1}$ \\ ${ }^{1}$ Lipids Research Group, Cruess Hall, University of California, Davis, California 95616, USA \\ ${ }^{2}$ Division of Nutritional Sciences, Cornell University, Ithaca, New York 14853, USA
}

(Received 4 January 1993 - Revised 24 March 1993-Accepted 1 April 1993)

\begin{abstract}
Walker 256 carcinosarcoma cells $\left(1 \times 10^{4}\right)$ were injected into the right thigh muscle of Sprague-Dawley rats $(125 \mathrm{~g})$ consuming isoenergetic $(200 \mathrm{~g}$ fat $/ \mathrm{kg})$ diets containing 20,100 and $200 \mathrm{~g}$ maize oil $/ \mathrm{kg}$ and 180,100 or $0 \mathrm{~g}$ hydrogenated lard $/ \mathrm{kg}$ respectively. Ten rats from each dietary regimen were killed every 4th day. Tumours grew rapidly from day 0 to day 8 post-transplant regardless of dietary regimen. However, after $8 \mathrm{~d}$ more tumours regressed and there were fewer deaths in animals fed on $200 \mathrm{~g}$ maize oil $/ \mathrm{kg}$ compared with animals fed on 20 or $100 \mathrm{~g}$ maize oil $/ \mathrm{kg}$. Linoleic acid (LA) levels were higher in phospholipids (PL) of growing tumours than in regressing tumours whereas arachidonic acid levels in PL were lower in growing tumours indicating a possible alteration in the desaturation and elongation of LA. Serum prostaglandin $E_{2}$ levels were slightly lower in rats with regressing tumours than in rats with growing tumours.
\end{abstract}

Linoleic acid: Cancer: Lipids: Walker 256 carcinosarcoma : Growth

Walker 256 carcinosarcoma was discovered in 1928 as a spontaneous mammary tumour (Morrison, 1972). This tumour cell line has been used in many studies because it is easily transplanted, is species specific for rats and grows rapidly in the host animal. A palpable tumour usually develops within $4 \mathrm{~d}$ post-transplant and it can grow to a mean diameter of 20-30 mm within $8 \mathrm{~d}$ (Cho-Chung, 1974; Morrison, 1972; Krause et al. 1979; Owen, 1982; Varani \& Perone, 1985). If tumour growth is left unchecked the tumour can kill the animal within 1-3 weeks (Kwong et al. 1984). The growth and/or regression of Walker 256 carcinosarcoma is dependent on the number of cells injected into the recipient animal (Kwong et al. 1984). Injection of $1 \times 10^{4}$ tumour cells into the thigh of rats resulted in a logarithmic growth pattern for the first $8 \mathrm{~d}$ post-transplant followed by regression of a nonpalpable state by the 14th day post-transplantation. In contrast, injection of $2 \times 10^{4}$ tumour cells resulted in a similar growth pattern with no sign of regression of the tumour after $14 \mathrm{~d}$.

The Walker 256 carcinosarcoma grows rapidly, is quite invasive, and its growth is affected by nutrients. Dills et al. (1984) showed a direct relationship between the level of glucose in the diet and tumour growth, reflecting the limiting level of glycolysis in the rapidly dividing tumour cells. Cho-Chung and co-workers (Cho-Chung \& Gullino, 1973, 1974; Cho-Chung \& Berghoffer, 1974; Cho-Chung \& Clair, 1977) demonstrated that growth could be arrested by administration of dibutyryl cyclic AMP in certain instances.

Kwong et al. (1984) observed regression of tumours in rats fed on a semi-purified diet containing $200 \mathrm{~g}$ maize oil $(\mathrm{MO}) / \mathrm{kg}$ after $9 \mathrm{~d}$ post-transplant $\left(1 \times 10^{4}\right.$ cells initially) while tumours of rats fed on a diet containing only the corresponding fatty acids (derived from $\mathrm{MO}$ ) continued to grow, suggesting that components of the non-saponifiable fraction of maize oil might be involved in tumour regression. 
Other researchers have shown that the type of fat consumed by experimental animals affects the growth of tumours (Gammal et al. 1967; Hillyard \& Abraham, 1979; Cohen et al. 1986) and certain unsaturated fatty acids are more effective than saturated fats in enhancing mammary tumorigenesis (Hopkins \& Carroll, 1979; Hopkins et al. 1981). According to Brenner (1984), this may be related to eicosanoid synthesis, especially prostaglandin $\mathrm{E}_{2}\left(\mathrm{PGE}_{2}\right)$, from arachidonic acid (AA). $\mathrm{PGE}_{2}$, an immunosuppressant, is present in large amounts in human malignant tumour tissue (Doll et al. 1966; Karmali, 1980) and this can suppress normal immune responses. The Walker 256 carcinosarcoma produces $\mathrm{PGE}_{2}$ in ascites fluid (Varani \& Perone, 1985). Thus, the consumption of high levels of dietary linoleic acid (LA), a precursor of AA, may facilitate tumour growth by enhancing $\mathrm{PGE}_{2}$ synthesis.

In contrast, dietary $n-3$ polyunsaturated fatty acids (PUFA) apparently reduce mammary tumour growth (Doll et al. 1966; Berg, 1975; Bang et al. 1976; Nielsen \& Hansen, 1980). The $n-3$ fatty acids, in particular eicosapentaenoic acid (EPA), inhibit PGE $_{2}$ synthesis and this may be related to their antitumour effects (Lokesh \& Kinsella, 1988). Karmali et al. (1984) demonstrated that dietary fish oil decreased $\mathrm{PGE}_{2}, \mathrm{PGF}_{2 \alpha}$, 6-keto $\mathrm{PGF}_{1 \alpha}$ and thromboxane $\mathrm{B}_{2}\left(\mathrm{TXB}_{2}\right)$, and reduced the size of $\mathrm{R} 3230 \mathrm{AC}$ transplantable mammary tumour. However, in trials with Walker 256 carcinosarcoma we found no inhibition of growth or regression of tumours in rats fed on $200 \mathrm{~g}$ fish oil $/ \mathrm{kg}$ (J. M. Black, M. C. Nesheim and J. E. Kinsella, unpublished results). In contrast, preliminary studies revealed that tumours showed a dramatic regression after $9 \mathrm{~d}$ in rats fed on $200 \mathrm{~g} \mathrm{MO} / \mathrm{kg}$. This was associated with a reduction in AA levels in tumours, suggesting that $\Delta-6$ desaturase was inhibited, thereby reducing $\mathrm{AA}$ and subsequently $\mathrm{PGE}_{2}$ production.

To examine this possibility in more detail we conducted experiments to ascertain the effects of three levels of MO in an isoenergetic diet, on the growth, fatty acid composition of phospholipids, prostaglandin $\mathrm{E}_{2}$, and regression of Walker 256 carcinosarcoma.

\section{MATERIALS AND METHODS}

\section{Tumour}

Walker 256 carcinosarcoma was obtained from EG\&G Mason Research Institute (Worcester, MA, USA) and was propagated by trocar injection into the right thigh of a Sprague-Dawley rat weighing approximately $125 \mathrm{~g}$. Uniformly viable cells were routinely prepared according to the procedure of Kwong et al. (1984). At $8 \mathrm{~d}$ after injection of $2 \times 10^{4}$ cells the tumour was removed and homogenized in sterile saline $(9 \mathrm{~g} \mathrm{NaCl} / 1)$ to disperse the cells which were recovered, as described by Kwong et al. (1984). Tumour cell number was determined by haemocytometer and the cells were aseptically injected by syringe into rats (approximately $125 \mathrm{~g}$ ) for further propagation. Tumour propagation was carried through three generations before starting experiments (Kwong et al. 1984).

\section{Animals}

Sprague-Dawley rats (Blue Spruce Farms, Altamont, NY, USA); $n$ 150, 50-75 g initial weight) were fed on standard rat laboratory ration (Prolab Agway, Syracuse, NY, USA) for $2 \mathrm{~d}$ before feeding experimental diets. The rats were then randomly assigned to the three dietary regimens. Animals were housed individually in stainless-steel cages. Food and water were provided ad lib. and a $12 \mathrm{~h}$ light-dark cycle was maintained in the room. After 1 week the rats were injected in the thigh with $1 \times 10^{4}$ viable Walker 256 carcinosarcoma cells as described by Kwong et al. (1984). Animal weight, food consumption and tumour growth were recorded daily as described (Kwong et al. 1984). Ten animals from each dietary group were killed every $4 \mathrm{~d}$ from day 0 to day 16 following injection of the tumour cells. 


\section{Diets}

The three experimental diets (Table 1) were based on AIN-76 purified diets (American Institute of Nutrition, 1977). Total dietary fat was $200 \mathrm{~g} / \mathrm{kg}$ diet. Dietary fat was composed of 20, 100 or $200 \mathrm{~g}$ MO (Mazola Oil; CPC International, Englewood Cliffs, NJ, USA)/kg and 180,100 or $0 \mathrm{~g}$ hydrogenated lard (Kraft, Inc., Chicago, IL, USA)/ $\mathrm{kg}$ respectively. The hydrogenated lard contained less than $20 \mathrm{~g}$ linoleic acid (LA) $/ \mathrm{kg}$. Saturated, monounsaturated and $n-6$ diunsaturated fatty acids comprised approximately $99 \%$ of the fatty acid composition (Table 2). LA contributed 5.6, 13.2 and 23.2\% energy in the 20, 100 and $200 \mathrm{~g} \mathrm{MO} / \mathrm{kg}$ diets respectively.

The vitamin E level was held constant in all diets by adjusting the 20 and $100 \mathrm{~g} \mathrm{MO} / \mathrm{kg}$ diets with $\alpha$-tocopherol (Sigma, St Louis, MO, USA). Fresh diets were fed to the animals daily and uneaten food was discarded. Fresh diets were kept in sealed containers, flushed with $\mathrm{N}_{2}$ and stored at $-30^{\circ}$ until used.

\section{Analytical procedures}

Animals were anaesthetized with diethyl ether, the peritoneum was opened and blood was drawn from the dorsal aorta. Serum was separated from erythrocytes by centrifugation and $0.5 \mathrm{ml}$ serum was extracted for prostaglandin analyses as described previously (Bruckner $e t$ al. 1983; Lokesh et al. 1986). Tumour growth and size was analysed as previously described in detail (Dills et al. 1984; Kwong et al. 1984). The tumour tissue from the right thigh and the semi-membranosus muscle from the contralateral thigh were then excised from each animal. Representative samples of both the viable tumour and the muscle $(0.5 \mathrm{~g})$ were homogenized and extracted for prostaglandin analyses. All samples were immediately frozen in liquid $\mathrm{N}_{2}$ and stored at $-70^{\circ}$ until analysed.

\section{Prostaglandin analysis}

Serum, tumour and muscle were extracted in three volumes ethyl acetate and quantified by radioimmunoassay (Lokesh et al. 1986). The $\mathrm{PGE}_{2}$ antiserum had a cross reactivity of less than $1 \%$ with $\mathrm{TXB}_{2}$, 6-keto $\mathrm{PGF}_{1 \alpha}$, hydroxyeicosatetraenoic acid and AA.

\section{Lipid extraction and quantification}

Total lipids (TL) in diets and tissues were extracted using a modified hexane-propan-2-ol technique (Emilson \& Sundler, 1985). Tissue samples were homogenized in $50 \mathrm{~mm}$-Tris, $\mathrm{pH} 7 \cdot 6$, containing $1 \mathrm{~mm}$-EDTA before extraction. Following extraction, the organic phase containing the lipid was dried under vacuum and the total amount of lipid per $g$ sample was determined gravimetrically. Neutral lipids (NL) were separated from phospholipids (PL) using BondElute aminopropyl microcolumns (Analytichem International, Harbor City, CA, USA). The phospholipid classes were separated by TLC using a solvent system of chloroform-methanol-acetic acid-water (50:40:8:2, by vol.; Swanson et al. 1987) and PL classes were identified using PL standards (Sigma). Bands corresponding to PL standards were scraped and lipids were eluted from the silica gel with toluene. All fractions were saponified (Christie, 1982), fatty acids were converted to fatty acid methyl esters (FAME) by diazomethane (Lokesh \& Kinsella, 1985), and separated and quantified by GLC (5880A gas chromatograph; Hewlett Packard, Avondale, PA, USA) using a $60 \mathrm{~m} \times 0.75 \mathrm{~mm}$ SP2330 glass capillary column (Supelco, Bellefonte, PA, USA). Flow-rate was set at $6.0 \mathrm{ml} / \mathrm{min}$ and oven temperature was programmed at $5^{\circ} / \mathrm{min}$ from 140 to $240^{\circ} . \mathrm{H}_{2}$ was used for makeup gas at $20 \mathrm{ml} / \mathrm{min}$. FAME were identified by comparison of retention times with authentic FA standards (Lokesh \& Kinsella, 1985).

The $\alpha$ - and $\gamma$-tocopherol levels were determined in both MO and lard by a modified 
Table 1. Composition $(\mathrm{g} / \mathrm{kg})$ of diets fed to experimental rats for $23 \mathrm{~d}$

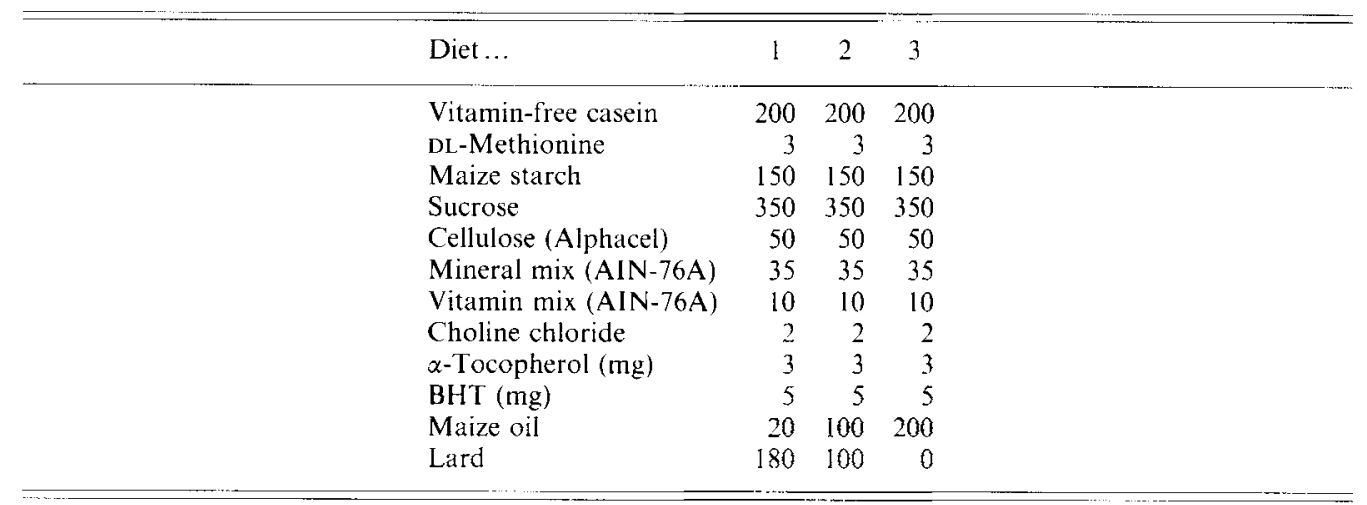

BHT, butylated hydroxytoluene.

Table 2. Fatty acid composition (mol/100 mol) of dietary fats fed to experimental rats for $23 d^{*}$

(Values are means with their standard errors for three analyses in each group)

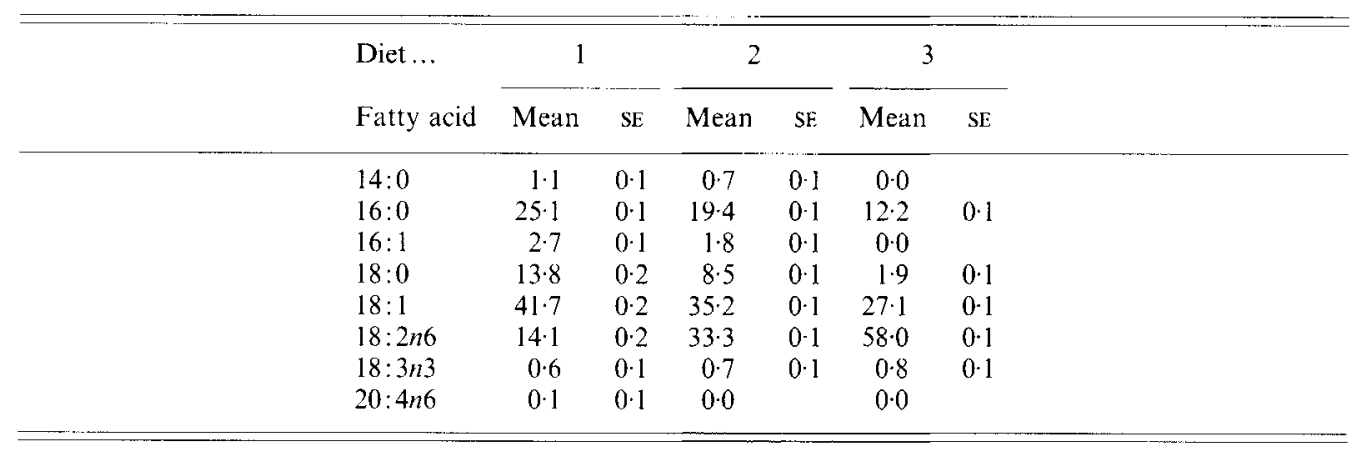

* For details of composition of diets, see Table 1.

HPLC method using a Waters Model M-45 solvent delivery system, a Whatman Partisphere c18 cartridge column and a Hewlett Packard 1040 Photodiode Array spectrophotometric detector (Chow \& Omaye, 1983). A methanol-water $(95: 5, \mathrm{v} / \mathrm{v})$ solvent system separated $\alpha$ - and $\gamma$-tocopherol and their esters. Total amounts of vitamin E were adjusted to $\alpha$ tocopherol by giving a potency value of $0.1 \alpha$-tocopherol $=1.0 \gamma$-tocopherol.

\section{Statistical analysis}

Changes in the concentrations of fatty acids, prostaglandins and vitamin E over time were analysed by analysis of variance (Snedecor \& Cochran, 1980). Means for each group were tested by Duncan's multiple-range test. Statistical analysis was performed using SAS Version 5 (SAS Institute Inc., 1985).

\section{RESULTS}

Animal weight gain and food consumption did not vary significantly $(P>0.05)$ among the groups over the experimental period. At approximately day 4 post-transplant, food consumption by all animals decreased to a minimum and then slowly increased from days 
12 to 16 . However, when the tumour weight was subtracted from total animal weight there was no gain in animal weight from day 4 post-transplant to day 8 , indicating that during this period the tumour was growing at the expense of the host.

\section{Tumour growth}

Palpable tumours were detectable around $4 \mathrm{~d}$ post-transplant in all 150 rats. Examination postmortem showed that the tumour had migrated above the femur into the semimembranosus muscle and as the tumour grew it appeared to consume the surrounding muscle. On the 8 th day post-transplant the tumour had developed a necrotic core while the outer layer was highly vascularized and viable. Between 8 and $12 \mathrm{~d}$ post-transplant the tumour had metastasized in some rats and lymph nodes were swollen. These animals showed no regression of the tumour. In rats in which tumour regression occurred the tumour mass appeared smaller, the viable outer layer thinner and regrowth of muscle tissue was apparent by $12 \mathrm{~d}$ post-transplant. Rats with regressing tumours recovered almost completely by the 16th day post-transplant and only a small necrotic mass was observed on examination post-mortem. The tumours that did not regress had a large necrotic core and a viable vascularized outer layer, which was weighed and recorded (Fig. 1).

Fifteen animals ( $10 \%$ of total) died from tumour growth during the study (Table 3 ). The first death occurred $8 \mathrm{~d}$ post-transplant with eight deaths occurring $9 \mathrm{~d}$ post-transplant. The remaining five deaths occurred during the last $2 \mathrm{~d}$ of the study. Of the deaths, $40 \%$ occurred in each of the groups of animals consuming diets with 20 and $100 \mathrm{~g} \mathrm{MO} / \mathrm{kg}$ while $20 \%$ of the deaths occurred in the group consuming diets with $200 \mathrm{~g} \mathrm{MO} / \mathrm{kg}$.

\section{Effect of diet}

No difference was observed in the growth rate of the tumour between diets for the first $8 \mathrm{~d}$ post-transplant; however, after day 8 tumour growth behaviour differed with each dietary regimen (Fig. 1). The average tumour weight of rats fed on 20 and $200 \mathrm{~g} \mathrm{MO} / \mathrm{kg}$ tended to decrease after $8 \mathrm{~d}$ post-transplant while the average tumour weight of rats fed on $100 \mathrm{~g} \mathrm{MO} / \mathrm{kg}$ tended to increase. Since each dietary group contained animals with growing and regressing tumours, the data were analysed according to tumour growth from day 8 to day 16 (the end of the study). Tumours that continued to grow were classified as growing tumours while tumours that became smaller after day 8 were classified as regressing tumours. Most of the regressing tumours were observed in rats fed on the $200 \mathrm{~g} \mathrm{MO} / \mathrm{kg}$ diet. Of the total tumours, $24 \%$ regressed in rats consuming $200 \mathrm{~g} \mathrm{MO} / \mathrm{kg}$ as compared with only $8 \%$ of all tumours in animals consuming $20 \mathrm{~g} \mathrm{MO} / \mathrm{kg}$, while tumours from rats fed on $100 \mathrm{~g} \mathrm{MO} / \mathrm{kg}$ exhibited an intermediate response.

\section{Lipid composition}

In order to determine whether the differences in growth and regression of the tumours were related to differences in lipid content and fatty acid composition, the lipids were analysed in detail. TL and total PL content in muscle and tumour tissue were comparable, i.e. $35 \mathrm{~g} \mathrm{TL} / \mathrm{kg}$ wet weight. The PL were approximately $15 \mathrm{~g} / 100 \mathrm{~g}$ TL.

Choline phosphoglyceride (PC) and ethanolamine phosphoglyceride (PE) comprised greater than $90 \mathrm{~g} / 100 \mathrm{~g}$ total PL in both muscle and tumour; the changes in fatty acid composition of muscle and tumour PC and PE were comparable (Tables 4 and 5). The LA and AA levels were the same in both PL classes, although docosahexaenoic acid (DHA) levels were much higher in PE than PC. However, the DHA and docosa-7,10,13,16,19pentaenoic acid (DPA, $n-3$ ) levels in PE of tumours rapidly decreased with tumour growth.

While muscle and tumour contained the same major fatty acids, muscle PC tended to contain more unsaturated fatty acids than tumour PC. The muscle PC contained a higher 


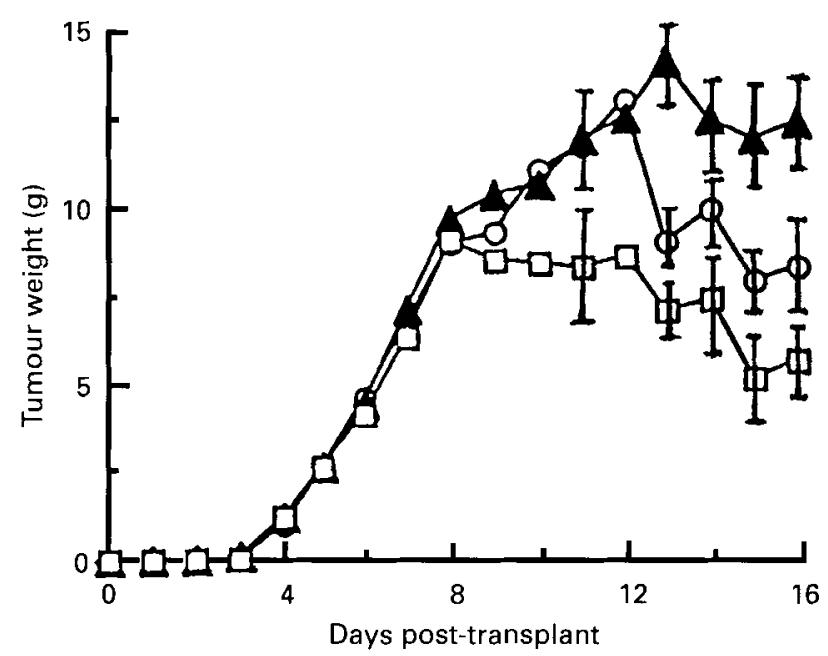

Fig. 1. Growth rate (post-transplant) of Walker 256 carcinosarcoma transplanted into the right thigh of experimental rats maintained on diets containing increasing levels $(\mathrm{g} / \mathrm{kg})$ of maize oil $:(\mathrm{O}), 20 ;(\mathbf{A}) 100 ;(\square), 200$. For details of diets and procedures, see Tables 1 and 2, and pp. 284-285. Tumour growth values (measured as described on p. 285) are daily means for each dietary group with their standard errors represented by vertical bars. $n=150$ at day 0 but decreased by at least 30 every 4 th day of post-transplant of the tumour to day 16 . The decrease in $n$ per dietary group was greater on days when rats died (see Table 3 ).

Table 3. The number of animal deaths at specific days post-transplant of Walker 256 carcinosarcoma from experimental rats fed on diets containing increasing levels of maize oil $(M O)^{*}$

(Values are nos. of deaths per day post-transplant of the tumour. Rats were maintained on the experimental diets $5 \mathrm{~d}$ before transplant of tumour into the right thigh and continued on diet until death)

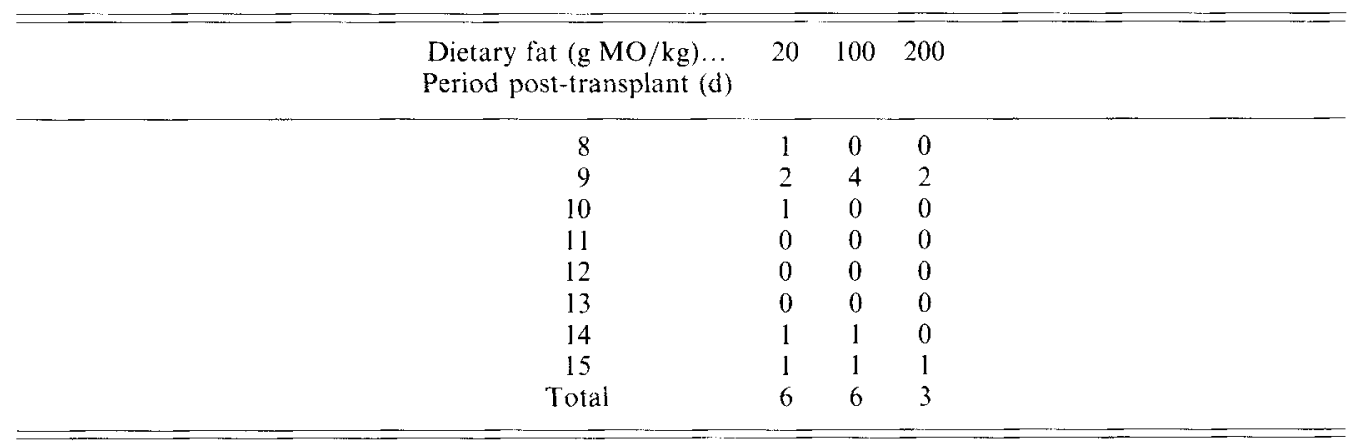

* For details of diets and procedures, see Tables 1 and 2 and p. 284.

amount of AA and DHA at day 8 post-transplant than did tumour PC. Muscle PE was more unsaturated than tumour PE because of its higher content of DHA.

The saturated fatty acids palmitic acid (PA) and stearic acid (SA) accounted for approximately $40 \mathrm{~g} / 100 \mathrm{~g}$ PL in both muscle and tumour (values not shown). These fatty acids did not change quantitatively in PL of muscle with time or the level of dietary MO. However, PA (mg/g) decreased from 422 to 240 , from 405 to 302 and from 373 to 322 in tumour tissue from animals fed on 20,100 and $200 \mathrm{~g} \mathrm{MO} / \mathrm{kg}$ respectively. The SA in tumour tissue $(\mathrm{mol} / \mathrm{g}$ ) increased concomitantly from 78 to 150,91 to 155 , and from 82 to 104 respectively, with increasing dietary MO. 


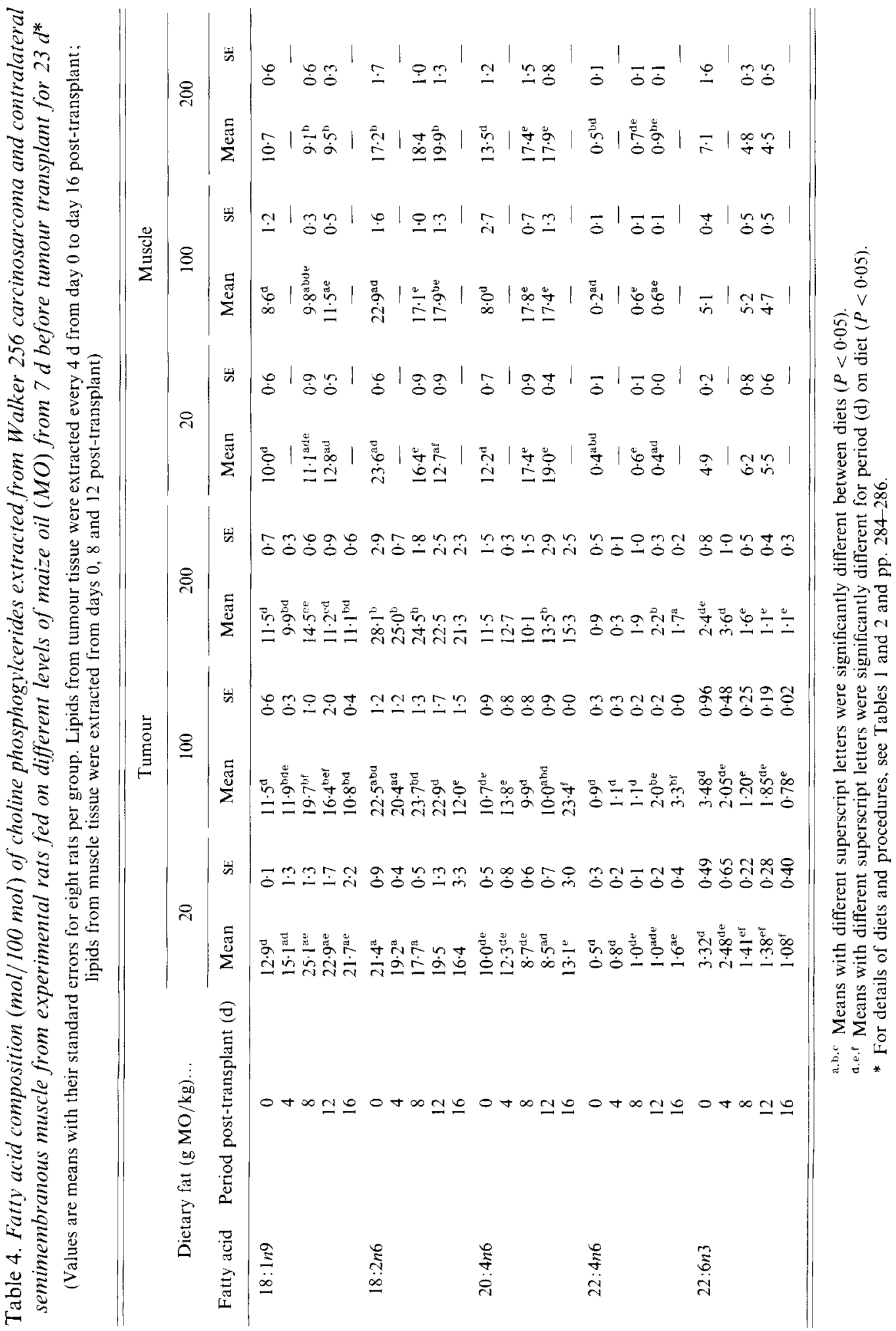




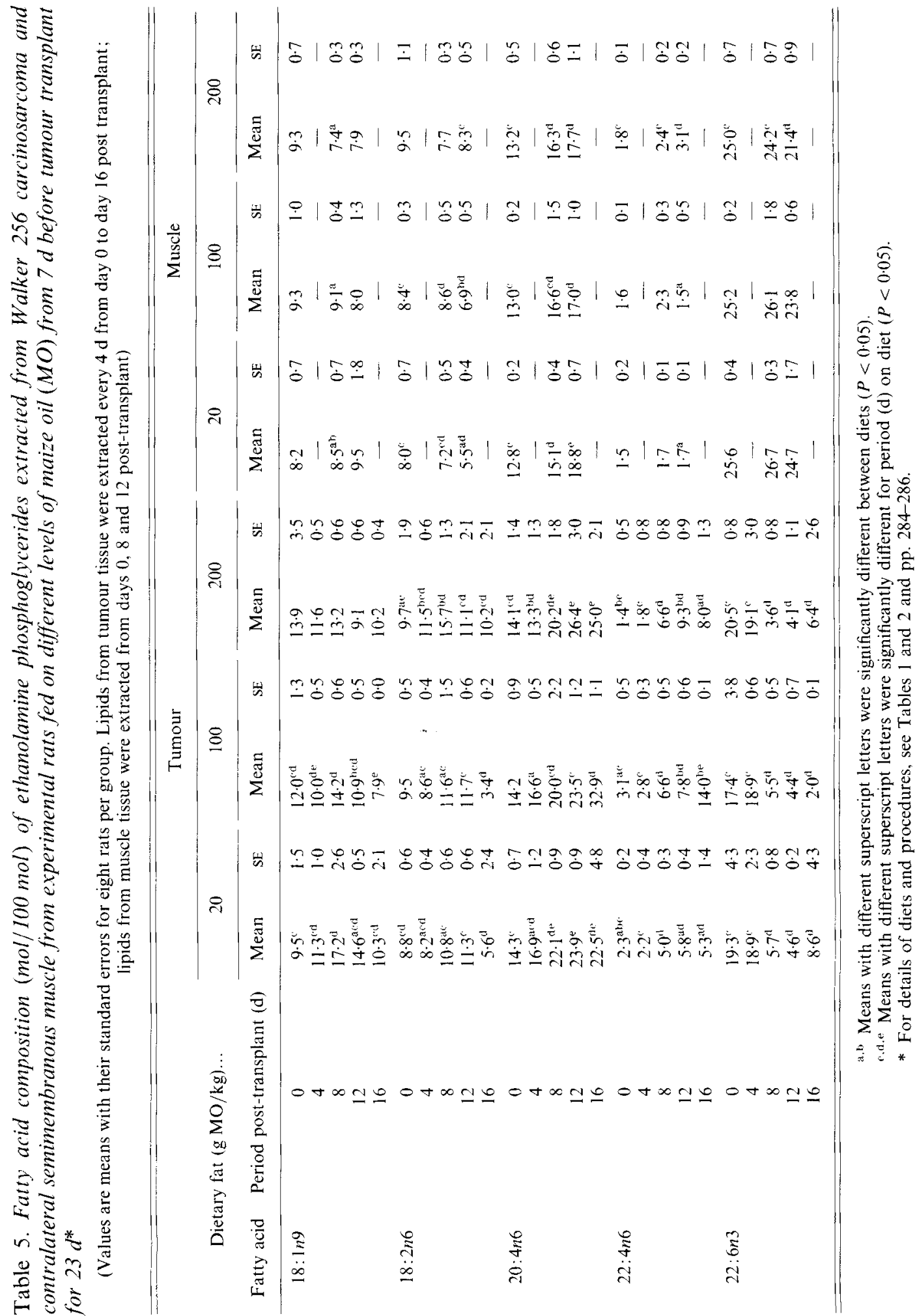


Table 6. Fatty acids (mol/100 mol) of choline phosphoglyceride and ethanolamine phosphoglyceride extracted from regressing or growing tumours in experimental rats fed on different levels of maize oil (MO) from $7 d$ before tumour transplant for $23 d^{*}$

\begin{tabular}{|c|c|c|c|c|c|c|c|c|c|}
\hline \multirow{3}{*}{$\begin{array}{l}\text { Tumour status... } \\
\text { Fatty acid }\end{array}$} & \multirow{3}{*}{ Dietary fat (g MO/kg) } & \multicolumn{4}{|c|}{ Choline phosphoglyceride } & \multicolumn{4}{|c|}{ Ethanolamine phosphoglyceride } \\
\hline & & \multicolumn{2}{|c|}{ Regressed } & \multicolumn{2}{|c|}{ Grew } & \multicolumn{2}{|c|}{ Regressed } & \multicolumn{2}{|c|}{ Grew } \\
\hline & & Mean & $\mathrm{SE}$ & Mean & $\mathrm{SE}$ & Mean & $\mathrm{SE}$ & Mean & SE \\
\hline $18: \ln 9$ & $\begin{array}{r}20 \\
100 \\
200\end{array}$ & $\begin{array}{l}19 \cdot 2^{c} \\
10 \cdot 8^{i d} \\
11 \cdot 1^{i}\end{array}$ & $\begin{array}{l}1 \cdot 2 \\
0 \cdot 4 \\
0 \cdot 7\end{array}$ & $\begin{array}{l}24 \cdot 7^{x} \\
14 \cdot 6^{d} \\
11 \cdot 2^{d}\end{array}$ & $\begin{array}{l}1 \cdot 9 \\
1 \cdot 0 \\
0 \cdot 5\end{array}$ & $\begin{array}{l}8 \cdot 7^{a} \\
9 \cdot 1 \\
9 \cdot 7\end{array}$ & $\begin{array}{l}2 \cdot 0 \\
1 \cdot 2 \\
1 \cdot 2\end{array}$ & $\begin{array}{l}15 \cdot 0^{\mathrm{he}} \\
10 \cdot 5^{\prime \prime} \\
9 \cdot 2^{\mathrm{di}}\end{array}$ & $\begin{array}{l}0.5 \\
0 \cdot 5 \\
0 \cdot 4\end{array}$ \\
\hline $18: 2 n 6$ & $\begin{array}{r}20 \\
100 \\
200\end{array}$ & $\begin{array}{l}12 \cdot 0 \\
12 \cdot 0^{a} \\
20 \cdot 6\end{array}$ & $\begin{array}{l}3 \cdot 3 \\
1 \cdot 5 \\
2 \cdot 1\end{array}$ & $\begin{array}{l}20 \cdot 9 \\
21 \cdot 6^{b} \\
25 \cdot 4\end{array}$ & $\begin{array}{l}1 \cdot 5 \\
1 \cdot 3 \\
1 \cdot 5\end{array}$ & $\begin{array}{l}3 \cdot 3^{a} \\
6 \cdot 2^{2} \\
9 \cdot 0^{a}\end{array}$ & $\begin{array}{l}0 \cdot 5 \\
2 \cdot 9 \\
1 \cdot 6\end{array}$ & $\begin{array}{l}11 \cdot 6^{b c} \\
11 \cdot 7^{b c} \\
15 \cdot 2^{b x d}\end{array}$ & $\begin{array}{l}0 \cdot 5 \\
0 \cdot 9 \\
0 \cdot 6\end{array}$ \\
\hline $20: 4 n 6$ & $\begin{array}{r}20 \\
100 \\
200\end{array}$ & $\begin{array}{l}17 \cdot 4^{a} \\
23 \cdot 4^{a} \\
16 \cdot 5\end{array}$ & $\begin{array}{l}2 \cdot 0 \\
0 \cdot 0 \\
2 \cdot 1\end{array}$ & $\begin{array}{c}7 \cdot 2^{b} \\
10 \cdot 3^{b} \\
8 \cdot 6\end{array}$ & $\begin{array}{l}1 \cdot 0 \\
1 \cdot 0 \\
0 \cdot 3\end{array}$ & $\begin{array}{l}22 \cdot 8 \\
31 \cdot 2^{\mathrm{a}} \\
27 \cdot 3\end{array}$ & $\begin{array}{l}6 \cdot 8 \\
1 \cdot 8 \\
2 \cdot 3\end{array}$ & $\begin{array}{l}23 \cdot 2 \\
23 \cdot 3^{\mathrm{h}} \\
21 \cdot 6\end{array}$ & $\begin{array}{l}0.9 \\
1 \cdot 3 \\
0.5\end{array}$ \\
\hline $22: 4 n 6$ & $\begin{array}{r}20 \\
100 \\
200\end{array}$ & $\begin{array}{l}2 \cdot 1^{a} \\
3 \cdot 3^{a} \\
2 \cdot 0\end{array}$ & $\begin{array}{l}0.3 \\
0 \cdot 0 \\
0 \cdot 3\end{array}$ & $\begin{array}{l}0 \cdot 8^{\text {bi }} \\
2 \cdot 0^{\text {hd }} \\
1 \cdot 8^{d}\end{array}$ & $\begin{array}{l}0.2 \\
0.3 \\
0.1\end{array}$ & $\begin{array}{c}5 \cdot 7^{\prime} \\
11 \cdot 6^{d} \\
9 \cdot 0^{\prime d d}\end{array}$ & $\begin{array}{l}1.9 \\
2.4 \\
1.0\end{array}$ & $\begin{array}{l}5 \cdot 8^{\prime \prime} \\
8 \cdot 2^{\prime \prime} \\
7 \cdot 9^{\prime \prime}\end{array}$ & $\begin{array}{l}0.5 \\
0.7 \\
0.4\end{array}$ \\
\hline $22: 6 n 3$ & $\begin{array}{r}20 \\
100 \\
200\end{array}$ & $\begin{array}{l}0.6 \\
0.8^{a} \\
0.9\end{array}$ & $\begin{array}{l}0.3 \\
0.0 \\
0.3\end{array}$ & $\begin{array}{l}1 \cdot 3 \\
1 \cdot 8^{\prime \prime} \\
1 \cdot 7\end{array}$ & $\begin{array}{l}0 \cdot 3 \\
0 \cdot 2 \\
0 \cdot 2\end{array}$ & $\begin{array}{r}10 \cdot 5 \\
2 \cdot 3 \\
5 \cdot 3\end{array}$ & $\begin{array}{l}5.6 \\
0.3 \\
1.8\end{array}$ & $\begin{array}{l}4 \cdot 3 \\
4 \cdot 4 \\
4 \cdot 8\end{array}$ & $\begin{array}{l}0.3 \\
0.9 \\
0.6\end{array}$ \\
\hline
\end{tabular}

LA and AA in PC of normal muscle changed with dietary $\mathrm{CO}$ content (Table 4). Thus, muscle LA decreased with time on $20 \mathrm{~g} \mathrm{MO} / \mathrm{kg}$, to a lesser extent on $100 \mathrm{~g} \mathrm{MO} / \mathrm{kg}$ whereas it increased with time in the muscle from animals consuming $200 \mathrm{~g} \mathrm{MO} / \mathrm{kg}$ (Table 4). AA tended to increase over time on all three diets.

The fatty acid composition of tumour PC was influenced by duration of diet regardless of level of dietary MO (Table 4). LA decreased while AA increased slightly with time (Table 4). Tumour docosa-7,10,13,16-tetraenoic (DTA) levels increased with all diets over time whereas it did not change in muscle. These changes indicated that, in contrast to muscle, the tumour possessed an active elongase enzyme which readily converted AA to DTA.

LA content was higher in the PL of growing than in regressing tumours (Table 6). Growing tumours had lower AA levels than did regressing tumours in animals on the different diets. The lower AA content in growing tumours was reflected in lower DTA as well.

\section{Prostaglandin $E_{2}$}

Serum $\mathrm{PGE}_{2}$ concentrations were similar among animals on the different dietary levels of $\mathrm{MO}$ (Table 7) while $\mathrm{PGE}_{2}$ concentrations in tumours varied with diet and time but showed no particular pattern. The levels of $\mathrm{PGE}_{2}$ were lower in serum from animals with regressing tumours (Table 8 ). The $P G E_{2}$ was very variable in both regressing and growing tumours. The mean concentration of $\mathrm{PGE}_{2}$ in normal contralateral muscle tissue was lower $(6 \cdot 0$

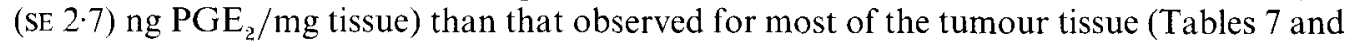
$8)$. 
Table 7. Prostaglandin $E_{2}\left(P G E_{2}\right)$ concentration of serum and tumour from experimental rats fed on different levels of maize oil $(M O)$ from $7 d$ before tumour transplant for up to $23 d^{*}$

(Values are means with their standard errors for six rats per group)

\begin{tabular}{|c|c|c|c|c|c|c|c|}
\hline \multirow{2}{*}{$\begin{array}{l}\text { Dietary fat }(\mathrm{g} \mathrm{MO} / \mathrm{kg}) \ldots \\
\text { Tissue }\end{array}$} & \multirow[b]{2}{*}{ Period post-transplant (d) } & \multicolumn{2}{|c|}{20} & \multicolumn{2}{|c|}{100} & \multicolumn{2}{|c|}{200} \\
\hline & & Mean & $\mathrm{SE}$ & Mean & SE & Mean & $\mathrm{SE}$ \\
\hline Serum (ng $\mathrm{PGE}_{2} / 0 \cdot 1 \mathrm{ml}$ ) & $\begin{array}{r}0 \\
4 \\
8 \\
12 \\
16\end{array}$ & $\begin{array}{l}3 \cdot 4^{\mathrm{alb}} \\
3 \cdot 0^{\mathrm{a}} \\
3 \cdot 6^{\mathrm{an}} \\
4 \cdot 5^{\mathrm{b}} \\
3 \cdot 8^{\mathrm{al}}\end{array}$ & $\begin{array}{l}0 \cdot 3 \\
0 \cdot 2 \\
0 \cdot 3 \\
0 \cdot 9 \\
0 \cdot 2\end{array}$ & $\begin{array}{l}4 \cdot 1 \\
3 \cdot 8 \\
3 \cdot 8 \\
4 \cdot 0 \\
4 \cdot 3\end{array}$ & $\begin{array}{l}0 \cdot 3 \\
0.3 \\
0.4 \\
0 \cdot 5 \\
0 \cdot 5\end{array}$ & $\begin{array}{l}4 \cdot 2 \\
3 \cdot 6 \\
4 \cdot 4 \\
3 \cdot 4 \\
4 \cdot 0\end{array}$ & $\begin{array}{l}0.5 \\
0.4 \\
0.7 \\
0.8 \\
0.4\end{array}$ \\
\hline Tumour (ng $\mathrm{PGE}_{2} / \mathrm{mg}$ protein) & $\begin{array}{r}0 \\
4 \\
8 \\
12 \\
16\end{array}$ & $\begin{array}{r}16 \cdot 8 \\
15 \cdot 4 \\
15 \cdot 7 \\
8 \cdot 6 \\
22 \cdot 3\end{array}$ & $\begin{array}{r}6 \cdot 2 \\
3 \cdot 3 \\
5 \cdot 9 \\
2 \cdot 8 \\
12 \cdot 7\end{array}$ & $\begin{array}{c}4 \cdot 4^{\mathrm{a}} \\
8 \cdot 9^{\mathrm{a}} \\
8 \cdot 2^{\mathrm{a}} \\
29 \cdot 5^{\mathrm{b}} \\
18 \cdot 4^{\mathrm{ab}}\end{array}$ & $\begin{array}{l}1.9 \\
0.9 \\
1 \cdot 7 \\
9.7 \\
7 \cdot 0\end{array}$ & $\begin{array}{r}4 \cdot 5 \\
9 \cdot 1 \\
13 \cdot 8 \\
23 \cdot 9 \\
12 \cdot 6\end{array}$ & $\begin{array}{r}1.7 \\
1.5 \\
1.5 \\
15.5 \\
3.5\end{array}$ \\
\hline
\end{tabular}

a.b) Means with different superscript letters were significantly different for period (d) on diet $(P<0-05)$.

* For details of diets and procedures, see Tables 1 and 2 and pp. 284-286.

Table 8. Serum and tumour prostaglandin $E_{2}\left(P G E_{2}\right)$ in regressing or growing tumours from experimental rats fed on different levels of maize oil $(M O)$ from 7 d before tumour transplant for $23 d^{*}$

(Values are means with their standard errors for eight rats per group)

\begin{tabular}{|c|c|c|c|c|c|}
\hline \multirow{2}{*}{$\begin{array}{l}\text { Tumour status... } \\
\text { Tissue }\end{array}$} & \multirow[b]{2}{*}{ Dietary fat (g MO $/ \mathrm{kg}$ ) } & \multicolumn{2}{|c|}{ Regressing } & \multicolumn{2}{|c|}{ Growing } \\
\hline & & Mean & $\mathrm{SE}$ & Mean & $\mathrm{SE}$ \\
\hline Serum (ng $\left.\mathrm{PGE}_{2} / 0 \cdot 1 \mathrm{ml}\right)$ & $\begin{array}{r}20 \\
100 \\
200\end{array}$ & $\begin{array}{l}3 \cdot 4 \\
3 \cdot 2^{\mathrm{a}} \\
3 \cdot 2\end{array}$ & $\begin{array}{l}0.5 \\
0 \cdot 5 \\
0 \cdot 6\end{array}$ & $\begin{array}{l}4 \cdot 8 \\
4 \cdot 6^{\mathrm{b}} \\
4 \cdot 6\end{array}$ & $\begin{array}{l}0.8 \\
0.3 \\
0.6\end{array}$ \\
\hline Tumour (ng $\mathrm{PGE}_{2} / \mathrm{mg}$ protein) & $\begin{array}{r}20 \\
100 \\
200\end{array}$ & $\begin{array}{l}26 \cdot 0 \\
12 \cdot 7 \\
18 \cdot 2\end{array}$ & $\begin{array}{r}21 \cdot 0 \\
2 \cdot 8 \\
7 \cdot 5\end{array}$ & $\begin{array}{l}10 \cdot 2^{\circ} \\
29 \cdot 6^{d} \\
13 \cdot 8^{\circ}\end{array}$ & $\begin{array}{l}2 \cdot 5 \\
7 \cdot 4 \\
1 \cdot 5\end{array}$ \\
\hline
\end{tabular}

a.b Means with different superscript letters were significantly different with tumour growth $(P<0.05)$.

$r, \mathrm{~d}$ Means with different superscript letters were significantly different between diets $(P<0.05)$.

* For details of diets and procedures, see Tables 1 and 2 and pp. 284-286.

\section{DISCUSSION}

Although tumour growth rate during the first $8 \mathrm{~d}$ post-transplant was apparently not affected, the amount of MO in the diet affected the regression of Walker 256 carcinosarcoma. With the highest amounts of MO in the diet there was a greater number of regressing tumours, a lower number of growing tumours after $8 \mathrm{~d}$, and fewer animals died on the $200 \mathrm{~g} \mathrm{MO} / \mathrm{kg}$ diet. Dietary MO did not alter significantly the fatty acid composition of either tumour or muscle tissue. The LA levels in phospholipids of regressing tumours were lower than in growing tumours while AA levels were somewhat higher, reflecting desaturase and elongase activities involved in the conversion of LA to AA (Kinsella et al. 1990). Higher LA and lower AA in both PC and PE indicated a decreased desaturase-elongase system which reduced the conversion of LA to AA. Several researchers 
have shown that inhibition of liver $\Delta 6$-desaturase results in increased LA and lower AA in rats (Bailey \& Dunbar, 1971; Shimp et al. 1982). Bailey \& Dunbar (1971) proposed that deletion of $\Delta 6$-desaturase activity signified the initiation of undifferentiated tumour cell proliferation; however, $\Delta 6$-desaturase has been reported for other continuous tumour cell lines in culture (Maeda et al. 1978).

The lower AA levels in growing Walker 256 tumours were not associated with lower $\mathrm{PGE}_{2}$ levels, although variability was high. The $\mathrm{PGE}_{2}$ levels in the tumour tissues were higher than those in the contralateral muscle. Serum $P E_{2}$ was lower in animals with regressing tumours and this was, perhaps, more significant because PGE $_{2}$ may be a general immunosuppressant (Kinsella \& Lokesh, 1990). Conceivably, the lower PGE 2 levels in circulation allowed tumour-killing cells to be more effective.

The lower levels of $n$-3 PUFA, e.g. DHA, in tumour tissue were noteworthy. The n-3 PUFA can suppress PGE $_{2}$ synthesis and reduce tumour growth in animals (Kinsella \& Lokesh, 1989; O'Connor et al. 1989; Kinsella et al. 1990). It is possible that there was less inhibition of the conversion of AA to PGE $\mathrm{PG}_{2}$ by 3 PUFA in animals with tumours. Kwong et al. (1984) reported that Walker 256 carcinosarcoma grew unhindered in rats fed on a diet high in MO fatty acids but regressed in rats fed on the same diet with the addition of the non-saponifiable matter of MO. However, we controlled the vitamin E content, a major component of non-saponifiable matter in the MO, by equalizing the tocopherol level in all diets. There was greater tumour regression and fewer deaths from tumour growth with increasing MO. Other researchers have reported that vitamin E level alone did not inhibit tumour formation but vitamin $E$ exerted a synergistic effect with Se in inhibiting mammary tumour growth (Horvath \& Ip, 1983).

In conclusion, dietary MO affected the regression of Walker 256 carcinosarcoma in rats. As dietary MO increased, fewer animals died and more tumours regressed. The present studies are consistent with the previous observation of Kwong et al. (1984) and suggest that agents other than tocopherol in the non-saponifiable matter of MO, e.g. tocotrienols, be involved in the antitumour effect. This will be examined in future studies.

\section{REFERENCES}

American Institute of Nutrition (1977). Report of the AIN ad Hoc Committee on standards for nutritional studies. Journal of Nutrition 107, 1340-1348.

Batley, 1. M. \& Dunbar, L. M. (1971). Lipid metabolism in cultured cells. Growth of tumor cells deficient in essential fatty acids. Cancer Research 31, 91-97.

Bang, H. O., Dyerberg, J. \& Hjorne, N. (1976). The composition of food consumed by Greenland Eskimos. Ac $7 a$ Medica Scandinavica 200, 69-73.

Berg J.W. (1975). Can nutrition explain the pattern of international epidemiology of hormone-dependent cancers? Cancer Research 35, 3345-3350.

Brenner, R. R. (1984). Effect of unsaturated fatty acids on membrane structure and enzyme kinetics. Progress in Lipid Research 23, 69-96.

Bruckner, G., Trimbo, S. \& Kinsella, J. E. (1983). Dietary trilinoelaidate: effects on hematological parameters, serum eicosanoids and tissue fatty acids in rats. Journal of Nutrition 113, 704-713.

Cho-Chung, Y.S. (1974). In vivo inhibition of tumor growth by cyclic adenosine $3^{\prime}, 5^{\prime}$-monophosphate derivatives. Cancer Research 34, 3492-3496.

Cho-Chung, Y. S. \& Berghoffer, B. (1974). The role of cyclic AMP in neoplastic cell growth and regression. II. Growth arrest and glucose-6 phosphate dehydrogenase isozyme shift by dibutyryl cyclic AMP. Biochemical Biophysical Research Communications 60, 528-534.

Cho-Chung, Y. S. \& Clair, T. (1977). Altered cyclic AMP-binding and db-cyclic AMP-unresponsiveness in vivo. Nature 256, 452-454

Cho-Chung, Y. S. \& Gullino, P. M. (1973). Effects of dibutyryl cyclic adenosine 3',5'monophosphate on in vivo growth of Walker 256 carcinoma: isolation of responsive and unresponsive cell populations. Journal of the National Cancer Institute 52,995-996.

Cho-Chung, Y. S. \& Gullino, P. M. (1974). In vivo inhibition of growth of two hormone-dependent mammary tumors by dibutyryl cyclic AMP. Science $183,87-88$. 
Chow $\mathrm{F}_{\mathrm{i}}$, \& Omaye T T. (1983). Use of antioxidants in the analysis of vitamins $\mathrm{A}$ and $\mathrm{E}$ in mammalian plasma by high-performance liquid chromatography. Lipids 18, 837-841.

Christie, W. W. (1982). Lipid Analysis. New York: Pergamon Press.

Cohen, L. A., Thompson, D. O.. Maeura, Y., Choi, K.. Blank, M. E. \& Rose, D. P. (1986). Dietary fat and mammary cancer. I. Promoting effects of different dietary fats on $\mathrm{N}$-nitrosomethylurea-induced rat mammary tumorigenesis. Journal of the National Cancer Institute 77, 33-42.

Dills, W. L. Jr, Kwong, E., Covey, T. R. \& Nesheim, M. C. (1984). Effects of diets deficient in glucose and glucose precursors on the growth of the Walker carcinosarcoma 256 in rats. Journal of Nutrition 114, 2097-2106.

Doll, R., Muir, C. \& Waterhouse, J. (1966). Cancer Incidence in Five Continents. New York: Springer-Verlag.

Emilson, A. \& Sundler, R. (1985). Studies on the enzymatic pathways of calcium ionophore induced phospholipid degradation and arachidonic acid mobilization in peritoneal macrophages. Biochimica et Biophysica Acta $\mathbf{8 4 6}$, 265-274.

Gammal, E. B., Carroll, K. K. \& Plunkett, E. R. (1967). Effects of dietary fat on mammary carcinogenesis by $7,12$ dimethylbenz( $\alpha)$ anthracene in rats. Cancer Research 27, 1737-1742.

Hillyard, L. A. \& Abraham. S. (1979). Effect of dietary polyunsaturated fatty acids on growth of mammary adenocarcinomas in mice and rats. Cancer Research 39, 4430-4437.

Hopkins, G. J. \& Carroll, K. K. (1979). Relationship between amount and type of dietary fat in promotion of mammary carcinogenesis induced by 7,12-dimethylbenz(a)anthracene. Journal of the National Cancer Institute 62, 1009-1012.

Hopkins, G. J., Kennedy, T. G. \& Carroll, K. K. (1981). Polyunsaturated fatty acids as promoters of mammary carcinogenesis induced in Sprague-Dawley rats by 7,12-dimethylbenz(a)anthracene. Joumal of the National Cancer Institute 66, 517-522.

Horvath, P. M.\& Ip, C. (1983). Synergistic effect of Vitamin E and selenium in the chemoprovention of mammary carcinogenesis in rats. Cancer Research 43, 5335-5341.

Karmali, R. A. (1980). Review: Prostaglandins and cancer. Prostaglandins Leukotrienes and Medicine 5, $11-28$.

Karmali, R. A., Marsh, J.\& Fuchs, C. (1984). Effect of omega-3 fatty acids on growth of a rat mammary tumor. Journal of the National Cancer Institute 73, 457-461.

Kinsella, J. E., Broughton, S. \& Whelen, J. (1990). Dietary unsaturated fatty acids: interactions and possible needs in relation to eicosanoid synthesis. Jothnal of Nutritional Biochemistry 1, 123-141.

Kinsella, J. E. \& Lokesh, B. R. (1990). Dietary lipids; eicosanoids and immune system. Critical Care Medicine 18, $100-115$.

Krause, R.. James, J. H., Humphrey, C. \& Fischer, J. E. (1979). Plasma and brain amino acids in Walker 256 carcinosarcoma-bearing rats. Cancer Reseurch 39, 3065-3069.

Kwong, E., Nesheim, M. C. \& Dills, W. L. Jr (1984). The influences of diet on the regression of the Walker carcinosarcoma 256 in rats. Journal of Nutrition 114, 2324-2330.

Lokesh, B. R., Hsieh, H. L. \& Kinsella, J. E. (1986). Alterations in the lipids and prostaglandins of mouse spleens following the ingestion of menhaden oil. Annals of Nutrition and Metabolism 30, 357-364.

Lokesh, B. R. \& Kinsella, J. E. (1985). Lipid composition and prostaglandin synthesis in mouse lung microsomes: alterations following the ingestion of menhaden oil. Lipids $\mathbf{2 0}, 842-849$.

Lokesh, B. R. \& Kinsella, J. E. (1988). Cancer, dietary fats and polyunsaturated fatty acids. National Medical Journal of India 1, 281-288.

Maeda, M., Osamu, D. \& Yuzuru, A. (1978). Metabolic conversion of polyunsaturated fatty acids in mammalian cultured cells. Biochimica et Biophysica Acta 530, 153-164.

Morrison, S. S. (1972). Feeding response to change in absorbable food fraction during growth of Walker 256 carcinosarcoma. Cancer Research 32, 968-972.

Nielsen, N. H. \& Hansen, J. P. (1980). Breast cancer in Greenland-selected epidemiological, clinical and histological features. Journal of Cancer Research and Clinical Oncology 98, 287-299.

O'Connor, T., Roebuck, B., Peterson, F., Lokesh, B. R., Kinsella, J. E. \& Campbell. C. (1989). Effect of dietary $\omega-3$ and $\omega-6$ fatty acids on development of azaserine induced preneoplastic lesions in rat pancreas. Journal of the National Cancer Institute 81, 858-863.

Owen, C. A. Jr (1982). Hypersensitivity to warfarin in rats with Walker 256 carcinosarcoma (41297). Proceedings of the National Academy of Sciences, USA 169, 1-3.

SAS Institute Inc. (1985). SAS User's Guide: Statistics, version 5 ed. Cary, NC: SAS Institute Inc.

Shimp, J. I., Bruckner, G. G. \& Kinsella, J. E. (1982). The effects of dietary trilinoelaidin on fatty acid and acyl desaturases in rat liver. Journal of Nutrition 112, 722-735.

Snedecor, G. W. \& Cochran, W. G. (1980). Statistical Methods. Ames, Iowa: The lowa State University Press.

Swanson, J. E., Black, J. M. \& Kinsella, J. E. (1987). Dietary n-3 polyunsaturated fatty acids; rate and extent of modification of fatty acyl composition of lipid classes of mouse lung and kidney. Journal of Nutrition 117 , $824-832$

Varani, J.\& Perone, P. (1985). Response of Walker 256 carcinosarcoma cells to 12-O-tetradecanoyl phorbol $13-$ acetate: possible regulation by endogenous cyclooxygenase metabolites. Journal of the National Cancer Institute 74, $165-172$. 